\title{
Deconstructing the Miltonic Exaggerations in Paradise Lost
}

\author{
Akram Nagi Hizam \\ College of International Studies, Southwest University, Chongqing, China
}

\begin{abstract}
Paradise Lost has become a controversial epic in misrepresenting characters especially among pious critics and religious scholars. Based on applying the deconstruction theory analysis on Paradise Lost, this paper discusses three main purposes about the Miltonic exaggerations in Paradise Lost: the infringement of God divinity, the high power position of Jesus Christ, and Oliver Cromwell; as the intended symbolic political figure by Milton.In fact, the Bible and the Holy Quran are considered two main sources to the paradise story, so they apparently deconstruct the Miltonic thoughts in this epic poem. According to deconstructionism in Paradise Lost, Milton consecrated the ideology of the Trinity concept which is not explicitly mentioned in the New Testament. He also exceeded the reasonable limitation of divinity by ignoring the role of the Great God and overstating the role of Jesus Christ as the whole mercy and justices. In addition, Milton came out with Paradise Lost after Oliver Cromwell's death in order to express his grief about Oliver Cromwell and the Commonwealth fall as well.
\end{abstract}

Index Terms-God, Jesus, Cromwell, infringement, exaggeration, Paradise Lost

\section{INTRODUCTION}

Although Milton had determined his purpose in Book I of Paradise Lost, "I may assert eternal Providence, and justify the ways of God to men" (Paradise Lost, 1999), he had gone beyond his aim and made too many overstatements about the God's divinity, Jesus Christ Power, and Oliver Cromwell's kingship in order to adjust his work to cope with the political events around England at his time. In fact, Paradise Lost is an epic poem that is still considered a literary masterpiece in the literary canon. It was written in blank verse by the English poet John Milton during the 17th century and It is regarded as the greatest work that was introduced by John Milton. The poem includes the biblical story that concerns with the fall of man, temptation of Adam and Eve, and Satan and how was their castigation from Garden of Eden. Indeed, Milton has used unique style, plot, and language to make his poem worthier but the fault that opens the gateway for scholars to have a different perception about Paradise Lost is his presenting to the truth and his overstatements about the characters. Since the beginning, Paradise Lost had attracted many disobedient readers and had disturbed others. For example, Dryden in The state of Innocence (1671) was an admirer of Milton's epic Poem as two men had different political affiliations. Dryden had supported Milton to employ his epic poem to cope with his thoughts. He thought that Satan who refused slavery and started to revolt against God to overturn his monarch is an unequivocal portrait of Oliver Cromwell, the king-killer. Shelley also regarded God and Satan as literary characters in Paradise Lost, and determined that Satan was represented rather better, he stated that 'Milton's Devil as a moral being' is, he writes, 'far superior to his God". William Blake is another critic who identified Milton as "a true Poet and of the Devil's party without knowing it". He hinted to Milton's overstatements that led him to depict Satan as a hero. In Milton's God (1961), William Empson seriously objected C.S. Lewis and others for their efforts in rehabilitation's God character and regarding Milton succeeded in justify the ways of God. Empson stated that "the reason why the poem is so good is that it makes God so bad". In fact, this paper focuses on the overstatements in Paradise Lost that must be taken into consideration because of their contrary to religion. For instance, unbalanced portray to any character especially in topics that are tightly related to religion leads into confusion among readers, and it may underestimate the value of religion. It also puzzles out the inscrutability that made many critics despise the God divinity due to Milton's misrepresentation to God's character in his epic poem. Since Paradise Lost is rich with different thoughts and many overstatements that came into view as contradictions, the theory of deconstruction can be applied to the text to show the negative side of it.

\section{INFRINGEMENT UPON GOD's DIVINITY}

Reading Paradise Lost with a religious perception shows up Milton's intention beyond the text. Milton has dedicated his thoughts either intentionally or unintentionally against God's divinity when he described God as the father. He depicts an image in the reader's mind that God behaves as human beings and He shares with them many characteristics. One of those characteristics is the growth process. Being a Father means having responsibility on his children, but Being Great God means having the responsibility of all creatures and being Supreme without any limitations to His Greatness. Milton consecrated the disparagement of the greatest divinity of God by misrepresenting him in Paradise Lost. Focusing on the whole epic poem illuminates how God was presented; His speech is dull and unpoetic and low number of lines are given to Him. In the first two books, God was totally absent, and when He was given a role to appear as a 
character, His first words were about having a Son, "Only begotten Son, seest thou what rage transports our Adversary?" (Paradise Lost, 1999). In fact, God must be unique and incomparable as He is. Not as what Milton wanted Him to be. The God described Himself in the Holy Quran, 42:11, "The originator of the heavens and the earth; He made mates for you from among yourselves, and mates of the cattle too, multiplying you thereby; nothing like a likeness of Him; and He is the Hearing, the Seeing". He means that He made mates for human beings and animals in order to multiply in this life, but he never pointed to His Majesty as having a son. Moreover, the God has specified a short chapter in the Holy Quran to clarify this controversial issue. He said "Say: He, Allah, is one. Allah is He on Whom all depend. He begets not, not is He begotten. And none is like Him" Quran112:1-4(Translated by A. Y. Ali). "Allah" is Arabic Word which simply means "The God" The Creator God. The nature of God is totally unique here. The God indicated to us His nature in a few words, to be easy for us to understand, while there are many qualities of God are described in numerous places in the Holy Quran. e.g., in 59:22-24, 62:1, and 2:255. Here the God only teaches us how to avoid the pitfalls into which many people and nations have fallen at various times while they were trying to understand God. Milton is one of those who have fallen into the pitfall when he described God as Godfather and not only this but he has passed the boarders to depict Jesus Christ as the Son who helps his father in making actions. So, the Great God character appeared in need to others like Jesus and this image contradicts what was mentioned in the Holy Books. The God also clarified that there are wrong excesses were made by Christians after Jesus' crucifixion in his last Holy Book which was sent after Jesus' crucifixion. And Milton's speech about the God one of those committed excesses. The God has stated this issue in the Holy Quran "O People of the Book! (The Bible). Commit no excesses in your religion: Nor say of Allah aught but the truth. Christ Jesus the son of Mary was (no more than) a messenger of Allah," (Quran 4:171). Paradise Lost proves the truth of this verse when Milton presented Jesus Christ as the Son of God. Now the question that raises up "why did Milton insist on presenting the character of Jesus in Paradise lost as a Son of God? Indeed, Milton only consecrated the ideology of the Nicene Council in 325 C. E and the Council at Chalcedon in 451 C.E. The former declared Jesus to be both fully God and fully man and the latter entrenched the doctrine of the Trinity into Christian theology in which God was represented in three successive modes: first as the Father, the second as the Son, finally as The Holy Spirit. At that time, the Roman Orthodoxy had considered a large portion of the Christian as heretics, because they believe in the concept of the Trinity which is not explicitly mentioned in the New Testament (Aslan, 2011). If we transported back to the third century, we will find that this term was considered new among the early Christian communities and there were many contradictions in the Christian societies for example, Montanism movement which was under the leadership of Tertullian. Montanist believed that Jesus had the same divine quality as God, but not in the same quantity as God. Nestorian Christians also believed that Jesus had two different natures- human and divine. In addition to that, there were those like Arians, they didn't believe in the Trinity, but they asserted the belief that Jesus is the Son of God. In fact, all these contradictions prove that the early conflicts among Christians as a whole led to chaos in writing about God's divinity. A close reading to the text will to some extent discern Milton's exaggeration about Jesus and ignoring in somehow the role of The Lord God. "Of Man's first disobedience, and the fruit of that forbidden tree whose mortal taste brought death into the World, and all our woe, with loss of Eden, till one greater Man restore us, and regain the blissful seat," (Paradise lost,1999). In the first four lines Milton described the disobedience of Adam and Eve as it is known everywhere, then he shifted to the Great Man. He means Jesus Christ. He totally ignored the forgiveness of God. Moreover, he gave the role of God to Jesus Christ whom never mentioned in any book in direct verse that he participated in this story. If we come to The Old Testament about the story of Paradise. There were four characters no more. Lord God, Adam, Eve and Satan (Genesis 3:7- 21). In the Bible Jesus Christ especially in this story was totally absent while in Paradise Lost, his role was more important than anyone else. In the Holy Quran also, God stated how He dealt with Adam "But his Lord chose him (for His Grace, he refers to Adam): He turned to him, and gave him Guidance. He said: "Get ye down, both of you, - all together, from the Garden, with enmity one to another: but if, as is sure, there comes to you Guidance from Me, whosoever follows My Guidance, will not lose his way, nor fall into misery" (Quran 20:122-123). This verse explains that God only who restores us, and regain the blissful seat. His condition is to follow his guidance otherwise we will run into misery life forever. In fact, Milton's plot was interesting for those people who don't know about the divinity of God and more antipathetic to believers. Many critics had exposed to Milton's failure in portraying the character of God in Paradise Lost, some of them are less pious like shelly and Blake, who believed Satan to be the hero of Paradise Lost and some are pious like Alexander pope. Shelly described in his defense of poetry that God was portrayed in a less important way "Milton's Devil as a moral being is as far superior to his God as one who perseveres in some purpose which he has conceived to be excellent in spite of adversity and torture, is to one who in the cold security of undoubted triumph inflicts the most horrible revenge upon his enemy" (Richter, 2007). In the same critical way as Shelly, William Blake behaved in criticizing Milton. Blake found that Milton presented God as inferior while Satan was presented as superior, he also considered Milton as unwitting Satanist (Flannagan, 1998). Alexander Pope also thought that Milton portrayed the God-father as less perfectly good and instantly sympathetic. He blew up Milton in his first epistle of the second book of Horace limited "God the Father turns a School-divine" (Pope, 1963).

\section{The High Power Position of Jesus Christ in PARAdise Lost}

In the Third book, Milton began his book with a tricky sentence to grab the reader's attention in order to trigger them 
towards the disbelief trap. He said "Hail, holy Light, offspring of Heaven firstborn, Or of the Eternal coeternal beam, May I express thee unblam'd?” (Paradise Lost, 1999). Milton realized that inventing deceptive ideas puts him in a place of reproach, for this reason, he was doubting whether to be blamed or not. Then he started to tip off his hidden thoughts about Jesus existence. He said "Before the Heavens thou wert, and at the voice of God, as with a mantle, didst invest" (Paradise lost, 1999). Milton did believe Jesus was born before the heavens, while the opening verse in the Bible didn't expose to Jesus existing before heavens. The Bible opened with this verse "In the beginning God created the heaven and the earth" (Genesis 1:1). Milton's description contradicts the Bible which is considered a Holy Book, so, this is enough proof to show that Milton resorted to fabrications in his work in order to convince his followers. Now, the most important thing is how Milton drew a map in the reader's mind to guide them to the misleading way without any critical thinking. Before he shifted to talk about mercy, mediation, power, Sacrifice, he had formerly convinced the reader with Jesus existence in heaven before creation. He also stated that God has announced his last judgement on Adam, when he said

I form'd them free: and free they must remain,

Till they enthrall themselves; I else must change

their nature, and revoke the high decree Unchangeable, eternal,(Paradise Lost,1999).

Milton fabricated his own barriers to inform us that Adam lost the mercy of God, and what he had to do in order to get rid of this dilemma is looking for mediation to bring the grace back. He depicted Jesus as a mediator who took on an initiative to intercede for Adam before God. In fact, Mediation before God considers pronounced blasphemy, because God is the most Compassionate, the most Beneficent, The One who has plenty of mercy for the believers and the blasphemers in this world and especially for the believers in the hereafter. God has based his rules, so if anyone commits a sin he has to demand mercy from God, without any mediator. God clarifies in the Holy Quran, how he forgave Adam. "Then learnt Adam from his Lord words of inspiration, and his Lord Turned towards him; for He is Oft-Returning, Most Merciful" (Holy Quran 2:37). God is the most merciful, He never needs any negotiation in order to give His mercy, He is The All-knowing, The Knowledgeable, The Patient, The One who does not quickly punish the sinners because His mercy comes before His wrath, they might return. And He is The Responsive, The Hearkener, The One who answers the one in need if he asks Him and rescues the yearner if he calls upon Him. The grace and mercy of God in which God asserts his love according to Milton's poem, they have transferred to be upon Jesus Christ. Moreover, he confirms repeatedly that Jesus Christ is the only power that can finally establish a bond of understanding between heaven and earth. Milton tried to describe Jesus Christ in his poem as the following "Divine compassion visibly appeared, Love without end, and without measure Grace" (Paradise Lost, 1999). He exaggerated when he depicted Jesus Christ as the God who never has a limitation to his Mercy. God has clarified in the Bible in 43 verses that He is the most merciful, He said "His mercy endureth forever" 1 Chronicles 16:34, 16:41.

2Chronicles5:13,7:37:6,20:21,.Erza3:11,psalms100:5,106:1,107:1,118:1,118:4,118:29,136:1,2,3,4,5,6,7,8,9,10,11,12, 13...26,138:8,.Jeremiah33:11.In all these verses God pointed to His mercy and He stated that His mercy is the only mercy stay forever. Milton portrayed Jesus as the most merciful when he depicted him as the whole mercy who negotiated the Great God to transfer His mercy upon him in order to rescue Adam of punishment. The most important clue that there is no any verse either in the Bible or in the Holy Quran that clarifies the mercy of Jesus upon Adam, So What came in Paradise Lost is totally different from the Holy Books. In other words, it is considered fake by believers. Although Milton represents Jesus Christ as the Mercy and all power, he exceeds the reasonable limitation by regarding God as unable to have the mercy and justice together. This considers as pronounced blasphemy. He depicts God as He needs, someone to act for Him, a God-figure who can also be Mediator. The God has already rejected such as allegations in all Holy Books. It was clear enough that Milton has highly motivated to depict Jesus Christ as a merciful who can take into consideration the repentance and atonement of Adam and Eve, While The God's mercy and love have been ended when the God put them on Jesus Christ. It is unfair that the mercy and love of God go through one of the creatures before it reaches to humans. God is the most merciful and the most gracious, so there is no limitation to His mercy to prove this idea from the words of God in the Holy Quran. He said: "(As for) My chastisement, I will afflict with it whom I please, and my mercy encompasses all things; so I will ordain it (especially) for those who guard (against evil) and pay the poor-rate, and those who believe in our communications" (Quran, 7. 156)

\section{Oliver Cromwell; AS the InTEnded Symbolic Political Figure By Milton}

Interpreting the intended symbolic political figure in Paradise Lost requires knowing the background history of Milton before and during producing Paradise Lost. John Milton was an important figure not only in prose and poetry but also in politics which played a significant role in his life. Although he was a minor figure when he started to write a poem about Shakespeare, later he became famous when he started his writing in a pamphlet war. When Charles I was executed in 1649, the events around that period of time and its consequences led Milton's political writings to be dominated. Within two weeks, he has published a justification of proceedings against Charles, The Tenure of Kings and Magistrates, which was written while the trail was in progress. Because of his writings, a month later, he was rewarded a position of power in the Commonwealth as a Secretary for Foreign Tongues to the Council of State. Henceforward Milton's duty was not only responsible for holding much of the commonwealth correspondence but he was also work- 
ing as a chief propagandist. Moreover, he published three works between 1649 to 1651; Observation upon the articles of Peace, Eikonoklastes, and pro Populo Anglicano Defensio. In 1660, When Charles II returned, Milton Published two works in which he endeavored to discontinue the tide: The Readie and Easie way to Establish a Free Commonwealth, in which Milton warns against the dangers inherent in a monarchical form of government, and Brief Notes upon a Late Sermon, in which Milton supported more despairingly that if there have to be a king, it would be better to elect one rather than restore the Staurts (Helena,1999).Since 1660 to 1674,Milton hardly fleed with his life at restoration and he devoted himself to write Paradise Lost and then Paradise Regained.The political contexts that were writen by Milton in order to advocate the commonwealth from 1649 to 1660 , the translated works into latin , and his position in the commonwealth also determined that there was no any doubt that milton wrote Paradise Lost as political obsession after the rule of Oliver Cromwell.He expressed his grieve about Oliver Cromwell and the fall of the Commonwealth by Writing Paradise lost to Keep Oliver Cromwell as its hero. Milton resorted to write his epic in a religious style in order to give a hint of his hero belief who used to derives his power of his religious belief "Cromwell had astonished the world, and gratified some republican political theorists, by showing that a strong state could be built, as it seemed, from scratch. Fortified by his belief in God's providence" (Hirst,1999). Studying both historical contexts from 1649 to 1664 and Paradise Lost gave a hint that there was a relevance among them. In Paradise Lost, Milton hinted to Charles II revenge, when he depicted that Satan came back to Paradise again to revenge from Adam and Eve after he has been cast out. Because there is no any clue nither in the Bible nor in the Holy Quran that proves Satan's return. Quran clarified that Satan has been cast out once from paradise, but he,satan, has disobeyed the God twice while he was in paradise and his punishment was as the following; In the first time, he lost his high honorary place to be in a low place, and the second time, when he was kicked out to the hell.This allusion gave us a clue that Milton might use Satan's returning in order to represent Charles II when he came back to revenge for his father's execution. Charles II revenged on 30th January 1661, th 12th anniversary of Charles I's execution.He command his fellowers to dig up the greive of Olivers Cromwell to bring out the body.Oliver Cromwell's body was hung all day before it was beheaded (Fitzgibbons, 2008). According to Paradise Lost, Satan had some disobedient angels who were negotiating or supporting him ,in the opposite side, In the Quran and the Bible ,the two Holy Books which are considerd the first sources to this Story, there is no any hint that some angels were fellowers to Satan in paradise as obedients. This argunent also confirm that Satan's fellowers were a symbol to CharlesII's fellowers.Milton's grieve upon Oliver Cromwell transported him back to rememer Paradise Lost disobedience ,and Adam's and Eve's sin. When Milton attended St. Paul's school and then Crist's College ,Cambridge; he exposed to the Bible's Studeies in which he became acknwelgable. Morever,He received a religious books from Thomas Young in Hamburg which became as trove knowledge in Milton's room. "On 26 March he wrote from London to Thomas Young in Hamburg, thanking him in Latin prose for the gift of a Hebrew Bible and enclosing a copy of a verse letter which was later published as Elegia quarta"(Campbell, 2008).All the previous studies and religious books gained him a privilege. In Paradise Lost, Milton minimized Adam's role and made Satan's role as a hero. He behave in such way to blame Adam and Eve who are considered the first couple that brought death and sin to huminity according to Puritanism belief. Milton believed that sin not only prevent people of being slave ,but it is also main reason to their death. In the Epistle to the Romans, the Apostle Paul explains that "the wages of sin is death; but the gift of God is eternal life through Jesus Christ our Lord." So Milton expressed about his king death by presenting Jesus Christ to condole himself and Oliver Cromwell's fellowers.

\section{CONCLUSION}

Exaggeration can be either positive or negative.It has been used too much in different fields such as Literature,Philosphey,Arts, and Religion in order to evoke stong feelings or to create an impression.In fact,exaggeration is almost affirmative,but it becomes unfavourable and loses its value when it exceeds the limitations of religion.For instance, when it transfers from the represen- taion of God to represent any creatures in the same excessive manner without taking into considerations the divinity and glory of God that must be incomporable.Paradise Lost is one of the litrary works, that is full with negative overstaments, in which God was potrayed as inferior while Jesus Christ and Satan were depicted as superior. Milton has resorted to exaggeration in Paradise Lost as a path to adapt his work to cope up with the events aroun England during his time.Milton had portrayed God in an unappropriate way untill God in Paradise Lost became known as the God of Milton among critics because he infringed God's Divinity and dipicted Jesus Christ and Satan in a high power position. Moreover, Milton wrote Paradise Lost after Cromwell's death in order to console himself and his fellowers with remembering the fall of man ,tempetation of Satan and Adam's and Eve's Sin which all are considered more severe with what happened to Cromwell. Finally,the arguments that are presented in this paper are based on the Holy Books; the Holy Quran and the Bible which are considered the main sources to this story.

\section{REFERENCES}

[1] Ali, A. Y. (1987). The Holy Quran(koran). Midinah: King Fahd Printing Complex.

[2] Aslan, R. (2011). No god but God: The origins, evolution, and future of Islam. Random House,New York.

[3] Bible, H. (2009). The New King James Version.Nashville: Thomas Nelson publishers.

[4] Campbell, G., \& Corns, T. N. (2008). John Milton: life, work, and thought.New York: Oxford University Press.

[5] Carroll, R., \& Prickett, S. (Eds.). (2008). The Bible: Authorized King James Version. New York:OUP Oxford. 
[6] DiTommaso, L. (1992). History and Historical Effect in Frank Herbert's" Dune". Science Fiction Studies 19.3, 311-325.

[7] Dryden, J. (1733). The State of Innocence, and Fall of Man: An Opera. Written in Heroick Verse. W. Feales at Rowe's Head, the Corner of Essex-Street.

[8] Empson, W. (1961). Milton's God. London, Chatto and Windus.

[9] Fitzgibbons, J. (2008). Cromwell's head. New York:Bloomsbury Academic.

[10] Helena, S. (1999). Cambridge Texts in the History of Political Thought.England:Cambridge university Press.

[11] Hill, C. (2011). Puritanism \& Revolution. Random House. England:Cambridge University Press.

[12] Hirst, D. (1999). England in Conflict 1603-1660: kingdom, community, commonwealth. New York:Bloomsbury Academic.

[13] Levak, H. (2017). God as a totalitarian figure in Milton's Paradise Lost (Doctoral dissertation, Josip Juraj Strossmayer University of Osijek. Faculty of Humanities and Social Sciences.).

[14] Milton, J., \& Flannagan, R. (1998). The Riverside Milton. Houghton Mifflin College Div.

[15] Milton, J. (1991). Milton: Political Writings. England:Cambridge University Press.

[16] Pope, A. (1737). The First Epistle of the Second Book of Horace Imitated...[Ornament]. T. Cooper, at the Globe in Paternoster-Row.

[17] Richter, D. H. (2006). The Critical Tradition: Classic Texts and Contemporary Trends 3rd Ed.Boston:Bedford/St.Marin's.

[18] Scott, J. (2000). England's troubles: seventeenth-century English political instability in European context. England:Cambridge University Press.

[19] Shelley, P. B. (1891). A defense of poetry. Boston: Ginn \& Company.

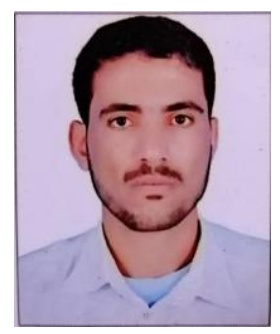

Akram Nagi Hizam was born in Aldhalea-Yemen. He is a teaching assistant at the Faculty of Education Aldhalea -Aden University. Currently, he is pursuing his Master degree in English language \&literature in Southwest University, Chongqing, China. He received a scientific excellence certificate from Aden University 2014 and he also earned other international certificates related to teaching English as foreign language. He used to be a translator at ICRC Aden -Yemen. His research interest includes the religious literature and oriental studies. 